\title{
Eight-Hour Study Time Management Mode for College Student Based on Credit System
}

\author{
Jing Xiong* \\ School of Computer and Information Engineering \\ Anyang Normal University \\ Anyang, China \\ jingxiong125@gmail.com \\ *Corresponding author \\ Lei Wang \\ School of Computer and Information Engineering \\ Anyang Normal University \\ Anyang, China
}

\author{
Aimin Wang \\ School of Computer and Information Engineering \\ Anyang Normal University \\ Anyang, China
}

\author{
Jiangde $\mathrm{Yu}$ \\ School of Computer and Information Engineering \\ Anyang Normal University \\ Anyang, China
}

\begin{abstract}
In order to solve the problem that more spare time but less rational time arrangement for college students, a study specification named eight-hour study mode is proposed. It requires students to ensure an average of eight hours per day and forty hours per week as basic study time. A key concept lesson ratio according to the characters and learning curve of lessons is also introduced. It can guide the students to schedule their study time purposefully. The eight hours study mode is conducive to university students finish their training objectives faster and better through independent study under the credit system.
\end{abstract}

Keywords- credit system; study specificatio; eight-hour study mode; lesson ratio

\section{INTRODUCTION}

Credit is an educational system followed in USA, Europe and other countries around the world. At present, the reform of credit system has fully implemented in domestic colleges and universities. Compared with the academic year system which has some problems such as too large class hours, too many required courses, having no course learning freedom and low autonomy learning [1], credit system has many advantages. However, there is also insufficient for credit system, such as more freedom of course selection, easily lead to the lack of sense of group honor; smaller binding force in learning process, easy to make learning organization slack [2]. Adopting diversified personnel training mode, credit system emphasizes students' self-study, class discussion, after-school practice, training practice and scientific research [3]. Therefore, under the credit management system, the learning process is mainly depending on the students' autonomy and self-consciousness. It requires that students have a strong ability of self management and self constraint. College students' time management under the environment of credit system is particularly important. But at present, there is blind arrangement in college students' afterschool life and there are negative effects than positive effects on college students [4]. Students' spare time arrangement has some problems, such as the lifestyle is not scientific, obsessed with the network and game, learning is the examination machine and ignoring the time planning [5]. Most of the students can't adapt to the self management mode, not reasonable time arrangement, and show a lack of self-control [6]. Rather than viewing time management as a singular concept, this research of [7] shows it is actually multidimensional, compromised of multiple time structure skills and behaviors.

Aiming to deal with these problems, a study specification named eight-hour study mode is proposed in order to standardize and restrain the college students to arrange their spare time reasonably.

\section{TIME DIVISION}

The college students' study and living time can be divided into six sections: rest time, exercise time, class time, self-study time, club activity time and others. The components and their distribution rate are shown in Figure I .

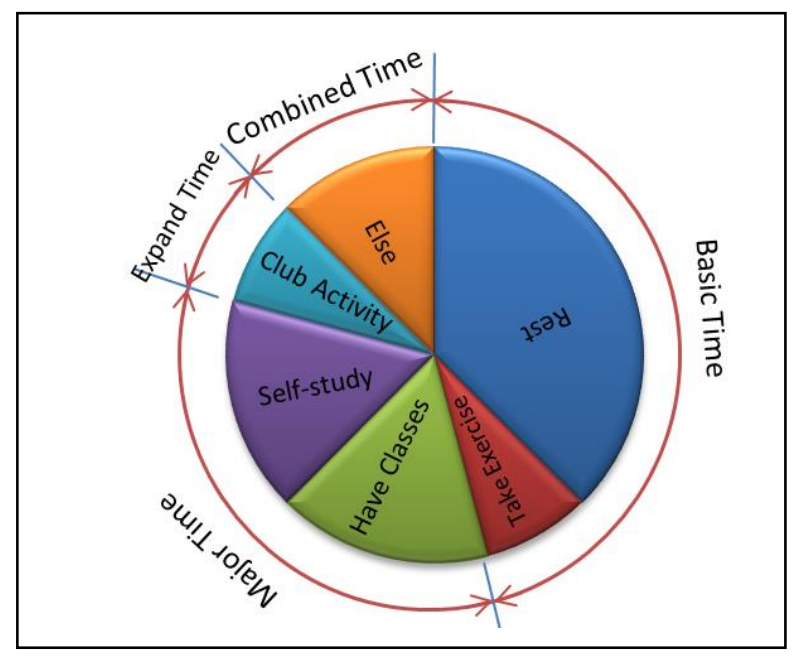

FIGURE I. TIME DIVISION OF COLLEGE STUDENT 
In Figure I, all the sections can split into four groups. The first one is basic time. It includes rest time and exercise time because college students must ensure adequate sleep and the right amount of physical exercise. The second one is study time including class time and self-study time, it is the major time. The third one is expand time which is used to positive community and club activities. Extracurricular activities play an important role in promoting students' interpersonal skills, communication skills and their overall quality. The last one is combined time which is composed of dining, shopping, making friends and travel. Students' main task is learning, so we focus on learning to study.

\section{EIGHT-HOUR STUDY MODE}

The 24 hours of one day for a worker are divided into three parts: 8 hours for work, 8 hours to sleep and the remains for free assignment. So we also propose the eight-hour study plan for college students. That is the college students should ensure spend 8 hours a day and 40 hours a week to study. The extra study time besides those eight hours one day is named flexible self-study time. It will be allocated by students themselves according to their interests.

The implementation principles of eight-hour study plan are as following: overall consider to semester, plan to week, arrange to day and action to hour.

\section{A. Overall consideration to semester}

After finishing the course selection each semester, the students should make that semester's study plan. They can arrange the time section of the term according to their schedule. All the parts including basic time, major time, expand time and combined time should have a general planning.

\section{B. Plan to week}

The eight-hour study mode requires students to ensure an average of 8 hours per day and 40 hours per week. Everyone makes one week's time management integrated planning according to his participation in community organizations, hobbies and habits. On weekends, students can either focus on various matters unrelated to study, or arrange flexible selfstudy time.

\section{Arrangement to day}

Research indicates that the sleep time of college students is generally not less than 7 hours a day. For Chinese students, get up at 6:30 and go to bed at 23:00 every day is a healthy lifestyle. Therefore, every day things should be arranged individually. Apart from rest, the other daily affairs will be arranged between 7:00-23:00.

\section{Action to hour}

Everyday study time should arrange to hours, so than it can ensure the implementation efficiency of the eight-hour study mode. First, according to the curriculum, the weekly courses are scheduled to every hour; second, schedule the self-study time by using study time difference (The time difference is equal to 8 hours minus the class time.); finally, arrange the remain matters between 7 am and $10 \mathrm{pm}$. It is important to note that some matters such as eating, physical exercise and extracurricular activities should be arranged in the fixed time.
All the things should be processed according to its emergency and important. Urgent means the things deadline is coming soon; non-urgent means there is a surplus of time before deadline. When we handle the matters, the important and urgent matters will be a priority to get them done. For important but not urgent matters students may be able to spend less time on them or postpone them temporarily. But they should not forget about them. Some matters are urgent but not important, and then students can decide to eliminate them even though they are coming up very soon. For not important and not urgent matters, if the students really are short on time, they should eliminate them decisively [8].

Figure II gives a computer professional schedule of some semester according to above principles.

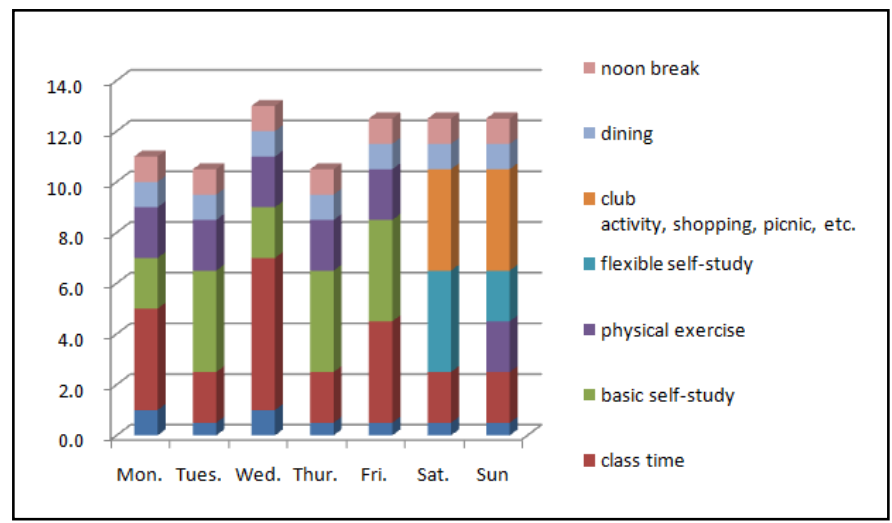

FIGURE II. A SAMPLE OF EIGHT-HOUR STUDY MODE

In Figure II, the first column represents the time interval rather than time point, for example, 7am means the periods of time from 7: 00 to 7:59. Unlabeled color part including the time speed on brushing, breakfast, cleaning, washing and housekeeping, etc.

The basic study time is the time from Monday to Friday, 8 hours a day and 40 hours per week. The study time besides eight-hour mode including minor or elective courses time at the weekend and the flexible self-study time. This part time will be independently arranged by the students according to their own circumstances.

\section{SELF-STUDY ARRANGEMENT PRINCIPLES}

College students have more independent learning time. Independent learning is one of the college students' essential ability, to arrange self-study time properly is related to the learning efficiency. However, self-study is not simply to complete the homework, but has a variety of forms such as preview, review, resourcing, practicing and paper or research report. Therefore, self-study time arrangement needs to follow the corresponding principle.

\section{A. First Come First Service for Review}

The consolidation of classroom knowledge can play a multiplier effect if students review them timely after class. Especially for strong practical disciplines such as computer science, after-school practice is the only way to acquire knowledge. Review time arrangement follows the "first come, first service" principle. That is to say, to arrange preview 
content according to the order of the curriculum. To master some extension knowledge students need to go to the library and borrow related literature. The course review which unable to complete within eight hours will be postpone to the next day's "eight hours".

\section{B. Shortest Remaining Time First for Preview}

College students always have less enough understanding of the importance of preparation before class. Their preview time arrangement is often not reasonable even have no preview time. There is large number of courses, if the same for each course and implement of all them, then it cannot reach the preview effect because of lack of time. So the preview follows the "shortest remaining time first " principle. That is to say, from the current time, the courses with shortest distance to next lessons have high priority, other courses prepare according to class time interval from short to long sequence.

\section{Lesson ratio assignment strategy}

Different course has different difficulties, descriptions and goals, so learn different courses need to pay different time cost. Therefore, in the self-study schedule, time unit allocation because of course difference, it needs to arrange according to the lesson ratio.

Lesson ratio is divided into review lesson ratio and preview lesson ratio. The former refers to the ratio of the minimum of review time cost mastering the knowledge and the corresponding class time; the latter is the ratio of the minimum preview time spent to easy to grasp the knowledge learned in the classroom and the corresponding class time.

College courses can be divided into three categories: public basic course, specialized core course and specialized course. According to the descriptions and goals, different courses need to set a different lesson ratio. Take computer science and technology major as an example, the lesson ratio is allocated as shown in Table I.

TABLE I. REFERENCE LESSON RATIO OF COMPUTER SCIENCE AND TECHNOLOGY

\begin{tabular}{|c|c|c|c|c|c|}
\hline & $\begin{array}{c}\text { Preview } \\
\text { lesion } \\
\text { ratio }\end{array}$ & $\begin{array}{l}\text { Preview } \\
\text { method }\end{array}$ & $\begin{array}{c}\text { Review } \\
\text { lesion } \\
\text { ratio }\end{array}$ & $\begin{array}{l}\text { Review } \\
\text { method }\end{array}$ & $\begin{array}{c}\text { Course } \\
\text { example }\end{array}$ \\
\hline $\begin{array}{l}\text { public } \\
\text { basic } \\
\text { course }\end{array}$ & $0.2 \sim 0.8$ & $\begin{array}{l}\text { reading } \\
\text { textbook }\end{array}$ & $0.5 \sim 1$ & $\begin{array}{l}\text { exercises, } \\
\text { further } \\
\text { reading }\end{array}$ & $\begin{array}{l}\text { Advanced } \\
\text { Mathematics } \\
\text { Computer } \\
\text { Basis }\end{array}$ \\
\hline $\begin{array}{l}\text { specializ } \\
\text { ed core } \\
\text { course }\end{array}$ & $0.5 \sim 1$ & $\begin{array}{l}\text { reading } \\
\text { textbook, } \\
\text { search } \\
\text { engine, } \\
\text { technical } \\
\text { forum }\end{array}$ & $1 \sim 1.5$ & $\begin{array}{l}\text { exercise, } \\
\text { experime } \\
\text { nt, } \\
\text { discussio } \\
\text { n, paper } \\
\text { or report }\end{array}$ & $\begin{array}{l}\text { Data } \\
\text { Structure, } \\
\text { Principles of } \\
\text { Computer } \\
\text { Composition }\end{array}$ \\
\hline $\begin{array}{l}\text { specializ } \\
\text { ed } \\
\text { course }\end{array}$ & $0.5 \sim 1.5$ & $\begin{array}{l}\text { reading } \\
\text { textbook, } \\
\text { search } \\
\text { engine, } \\
\text { technical } \\
\text { forum, } \\
\text { pair } \\
\text { program } \\
\text { ming }\end{array}$ & $\begin{array}{l}1.5 \sim 2( \\
\text { with } \\
\text { experi } \\
\text { ment); } \\
1.5 \sim 3( \\
\text { no } \\
\text { experi } \\
\text { ment) }\end{array}$ & $\begin{array}{l}\text { exercise, } \\
\text { experime } \\
\text { nt, } \\
\text { project, } \\
\text { paper or } \\
\text { report }\end{array}$ & $\begin{array}{l}\text { Advanced } \\
\text { Programmin } \\
\mathrm{g}, \quad \text { Software } \\
\text { Engineering }\end{array}$ \\
\hline
\end{tabular}

\section{REQUIREMENTS FOR TEACHERS}

The implementation of the credit system makes the students have a greater right to choose courses based on their hobbies, so that it easier to achieve greater development. However, there is a lack of sense of creativity and quality for college students, and the innovative education system is not perfect [9]. Currently, for the college students, the ability to find, analyze and solve problems is generally not high. Therefore, in credit system for teachers teaching put forward higher requirements.

In class, the students should be given more space to think and self-expression opportunities. When explaining some knowledge, do not straightforward, problem-driven style of teaching is a better way. To use contrast teaching methods and let the students to know why we should use this method rather than another one. Before the end of each lesson, students need to arrange to review the mandate and mission rehearsal, given a few questions, so that the students can preview and review lessons with questions. Tell students some reference books and websites related learning and encourage them use multiple channels to find solutions to problems. Promoting exchanges and discussion between students and encourage them to actively participate in academic competitions.

\section{CONCLUSION}

Currently the spare time of college students is more, but most time arrangement is unreasonable, poor effective utilization. Credit system put forward higher requirements to the students' self-study ability, reasonable arrangement study time is an important task. This paper proposed an eight-hour study mode in order to design a normative study plan for college students and guide them arrange and use their spare time effectively. Although, the research objects of this paper are the students of computer science and technology, but it can provide reference to other students whose major in Science and Engineering. This paper only considers the average level of the undergraduates, not for special students. In addition, the assessment criteria of the mode implementation also need further research.

\section{ACKNOWLEDGMENT}

This research is supported by Computer science and technology National Characteristic specialty (2009TS11576) and Henan comprehensive reform specialty Computer Science and Technology (2012-859-14) and Henan province science and technology key project (132102210264).

\section{REFERENCES}

[1] Mou Z. J, Xu R. C, Wang Q. H, Chen F. R and Yang B. Y, Research on local engineering college credit system construction and implement. Education Teaching Forum, 2013, pp. 281-282.

[2] Cai Y. M, College complete credit reform practice and exploration. Human Resource Management. 2010, pp. 179-181.

[3] Cai W.B, Take credit reform as a breakthrough to comprehensively improve the quality of personnel training. Journal of Shaanxi Normal University (Philosophy and Social Sciences Edition). 2003, pp. 214-217.

[4] Zhao L. N, Investigation of college life after school. Chinese school education. 2009, pp. 23-24.

[5] Zhu C. Y and Zhou M, Problems of contemporary college students spare time arrangements. Chinese market. 2011, pp. 174-176. 
[6] Yang J, Students develop healthy lifestyles mechanism. Journal of Henan Institute of Science and Technology University. 2010, pp. 69-71.

[7] Bartholomew, Christine P., Time: An Empirical Analysis of Law Student Time Management Deficiencies (August 26, 2012). University of Cincinnati Law Review, Vol. 81, No. 3, 2013, pp. 897-952

[8] Time M anagement for College Students. [2013-5-5] http://www.vgcc.edu/CounselingServices/Time-management.pdf.
[9] Zhang X. L, Li B. Q and Pan H. B, Research on the System of Innovative Talent Production for College Students in the Innovation Credit System. Journal of Higher Education Management. 2013,Vol 7, pp. 102-106. 